\title{
Célia Bertin: Jean Renoir - A Life in Pictures
}

\author{
By Gerald Pratley
}

Spring 1993 Issue of KINEMA

RECENTLY, the scholarly Alistair Cooke was introducing John Mortimer's Renoir reminiscent tv-film series, Summer Lease on PBS. In describing the origins of the story, which lay in the author's family visits to Italy, Cooke started a train of thought on the number of artists over the years whose work was inspired by their parents' activities, family relations, the tales they heard as children, the travels they took and the institutions they attended, all forming an important part of their growing years and providing them with a vivid background to draw upon in their creative periods which followed.

Co-incidentally, a new biography of the distinguished French filmmaker, Jean Renoir, the son the greatest painter of the time, provides us with a detailed and colourful description of how deeply influenced Jean was by his father, Auguste and family; and how much his films reflected this without in anyway detracting from Jean Renoir's own achievements in the cinema that were as original to his medium of motion pictures as his father's were to painting.

Renoir was born in Paris on September 15, 1894. Fifteen months later the cinema was officially born, also in Paris, where Louis and Auguste Lumière held the first public screening of their Cinématographe on December 28,1895 . The future filmmaker was two years old when his cousin, the 15-year-old Gabrielle Renard, took him to see his first film show. He screamed with fear throughout; by the time he was nine however, he was eagerly attending the Sunday afternoon "picture shows" in the parlour of his boarding school.

"The silver screen fascinated Jean," writes the author, Célia Bertin. "The magic of the darkened room and the mysterious purring of the projector made such an impression that his love of films soon surpassed that of all the other arts and entertainments" - to which he was well exposed.

He lived at the theatre, from Punch and Judy shows to stage productions and the Montmartre melodramas; to concerts, opera and the ballet. He was surrounded by paintings and sculptures and met Monet, Cézanne, Degas, among the many. Their house was filled with lively models, talkative artists and exciting people of all kinds. There were lots of friends and happenings, racy conversations where anecdotes and gossip flourished. He grew up wealthy, somewhat spoiled, elegant, sophisticated and a gentleman - and remained so until his death in 1979.

He was an artist who seldom talked about art, did not lie to reveal his personal self, wrapped himself in good humour and unfailing courtesy, respected women and always listened to what they had to say in a time when most other men did not. Everyone fortunate enough to have met and interviewed him remembers the passion and eloquence with which he spoke. He could bring tears to the eyes of the most sophisticated.

Charlie Chaplin, his idol as a youth and with whom, in later years, he became firm friends, inspired him to take up filmmaking, as did the work of Von Stroheim and D. W. Griffith. From this came such marvellous films as Nana, The Little Match Girl, La Chienne, Boudu Saved from Drowning, Madame Bovary, A Day in the Country, The Lower Depths, Grand Illusion, Rules of the Game, The River, and French Can-Can.

During World War II, saddened and disgusted with his country and its collaborators, he went to Hollywood. There his difficulties as a writer-director in Paris changed to becoming difficulties with the studio system-to which he could never belong and which never understood him. In spite of them he made several important and lasting films in the U.S.: Swamp Water, The Southerner, Diary of a Chambermaid and The Woman on the Beach.

After the war Renoir became a "man between" two countries. He came to love America more and France less, although he returned to make films there with the support of Truffaut and Bazin and those friends who had survived from pre-war years.

He became an American citizen and in the Hollywood hills at 1273 Leona Drive he built a house and garden with vines and bright flowers reminding him of his parents' home, Les Collettes; and he and his faithful wife 
Dido, his cousin Gabrielle, their companion, Bessie, and numerous other family members and friends, lived in "a kind of peace" as though back in Essoyes.

And, like John Mortimer, Renoir also wrote a book about his father; like him he continued to take sheer delight in his work infusing it with his wonderful sense of poetry. One way or the other he made over forty films.

There have been more than fifty books published about Renoir but none quite so complete and evocative of a life from silent cinema to television, from Paris, Rome, London, Berlin to Los Angeles, than this moving, perceptive and understanding study by Célia Bertin. She has drawn on previous books, letters and interviews, and cleverly combined these references with her own considerable and painstaking research into a profound whole.

First published in France in 1986 in French as Jean Renoir: cinéaste, this is the English edition translated by Mireille and Leonard Muellner. They use several doubtful phrases such as "he blew his top" and "to be blown away by his talent" among others, and there are some slips with places, titles and names; but these are minor. Madame Bertin merges revealing descriptions of how Renoir's films were made with a critical analysis and appreciation of them. Throughout his pre-war career in Paris he made films he believed in, but just as many went unrealised because producers, lacking his vision and imagination, refused to finance them.

Mindful of the political issues involved (there always are in France it seems) and of his rejections and disappointments, her narrative remains refreshingly free of sociological jargon. The end result is a memorable portrait of an artist living his own way and triumphing in his beliefs.

Toward the end of his long life, Renoir suffered terribly from a World War I leg injury and Parkinson's disease; yet he continued to write with courage and determination up until the morning he died. Writing was as easy for him as speaking - a talent for talking inherited from his father.

He summed up his career saying, "I believe that our function in film is above all to look at the world the way it is and to tell of it without putting coloured lenses in front of our eyes. This is called demystification."

Renoir was, indeed, a human being of the highest order.

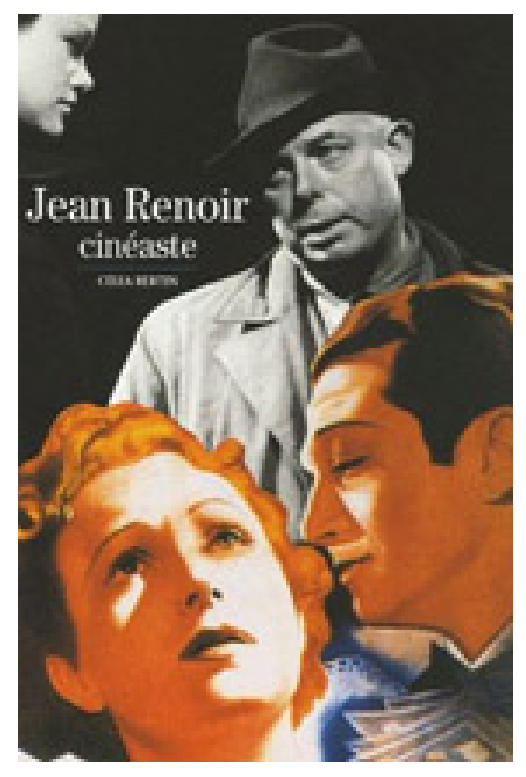

Figure 1: TITLE: JEAN RENOIR: A LIFE IN PICTURES \ BY: Célia Bertin $\uparrow$ PUBLISHER: Baltimore and London: The Johns Hopkins University Press 9 YEAR: 1991 I PAGES: 403pp. Ill. 


\section{Author Information}

Gerald PRATLEY, OC, LLD, started his career as film critic with the CBC. In 1969, he founded the Ontario Film Institute which he directed until 1990. He has written several books and numerous articles on film, including Torn Sprockets, a history of Canadian cinema. He taught Film History in universities in Toronto and Waterloo, Canada and holds three honorary degrees from Canadian and US universities.

Gerald A. Pratley (1923-2011) was born and educated in London, England, and came to Canada in 1946. He started working in Toronto for the $\mathrm{CBC}$ as a scriptwriter. He was drawn toward working in motion pictures, and became, in 1948, the CBC's first film critic and commentator.

Gerald Pratley broadcast three programmes a week, Pratley at the Movies, The Movie Scene, Music From the Films, and others, until 1975. During this time he also became the first post-war chairman of the Toronto Film Society, chairman of the Toronto and District Film Council and co-founder of the A-G-E Film Society and correspondent for international magazines such as Films and Filming, Film In Review, Variety, Hollywood Quarterly and International Film Guide. During the 1950s he wrote for Canadian Film Weekly and Canadian Film Digest.

He became known as a speaker on all aspects of motion picture art and industry, and was invited to teach film history at the University of Toronto, York University, University of Waterloo, Seneca College and Ryerson Polytechnical University, with individual lectures being given at many other Canadian and US universities and colleges. He has served as a member of various judging panels of competitions and festivals, being one of the members of the first Canadian Film Awards in 1949.

From 1970 to 1975 he was the director of the Stratford (Ontario) International Film Festival, and from 1969 to 1976 he was Chairman of the International Jury of the Canadian Film Awards. He has attended all the world's leading festivals of film, and in particular, for 30 years, the Cannes Festival as CBC correspondent. He has written six books, The Films of Frankenheimer: Forty Years in Film; The Cinema of John Frankenheimer; The Cinema of Otto Preminger; The Cinema of David Lean; The Cinema of John Huston, and Torn Sprockets, a history of the Canadian cinema.

Gerald Pratley has served on the Advisory Boards of the film departments of Ryerson Polytechnical University and Humber College, and as a member of the programme committee of TV Ontario. In 1968 he became the founder-director of the Ontario Film Institute of the Province of Ontario, an organization which has

distinguished itself in archival holdings and public service and is known since 1990 as the Cinematheque of Ontario. He taught Film History courses at the Department of Film and Photography, Ryerson Polytechnic University, Toronto and the University of Waterloo.

In 1984, Gerald Pratley was made a Member of the Order of Canada and in 2003 Officer of the Order of Canada for his service to Canada through film appreciation. He holds Honorary Degrees in Letters and Fine Arts from York and Waterloo Universities (Ont., Canada) and Bowling Green State University (Ohio, USA).

In 2002, Gerald Pratley received a Special Genie Award from the Academy of Canadian Cinema \& Television in recognition of his lifelong dedication to the promotion and his exceptional support of Canadian cinema.

He died on 14 March 2011 in Ontario, Canada. 